RU Мифология современного города в поэзии рубежа XIX-XX веков (Э. Верхарн, В. Я. Брюсов, Д. А. Гатуев)

Хетагурова Д. К.

\begin{abstract}
Аннотация. Цель работы - проследить влияние мифологической символики на создание поэтической картины мира города рубежа XIX-XX вв. (Э. Верхарн, В. Я. Брюсов, Д. А. Гатуев). Научная новизна исследования заключается в том, что европейская, русская и осетинская урбанистическая лирика модернизма недостаточно изучена с акцентом на общность эстетических установок. В результате анализа выявлены особенности трактовки мифологических, антропоморфных, анимистических образов мегаполиса: город-спрут, властвующий в пространстве, времени и в человеческом сознании (Верхарн); город-дракон, восседающий на «богатствах» современных Содома и Гоморры, стремящийся к собственной гибели от рук рабов (Брюсов); город-блудница, танцующая под аккомпанемент тапера-чёрта, который лишает горожан воли и индивидуальности (Гатуев).
\end{abstract}

EN

\title{
Mythology of Modern City in Poetry of the Turn of the XIX-XX Centuries (É. Verhaeren, V. Ya. Bryusov, D. A. Gatuev)
}

Khetagurova D. K.

\begin{abstract}
The purpose of the paper is to trace mythological symbolism influence on creation of the poetic worldview of a city at the turn of the XIX-XX centuries (É. Verhaeren, V. Ya. Bryusov, D. A. Gatuev). Scientific novelty of the study lies in the fact that the European, Russian and Ossetian urban lyrics of modernism are insufficiently studied with an emphasis on aesthetic attitudes commonality. As a result of an analysis, the researcher has identified the features peculiar to interpretation of mythological, anthropomorphic, animistic images of a metropolis: there is an octopus city that dominates space, time and human consciousness (Verhaeren); a dragon city sitting on the "riches" of modern Sodom and Gomorrah, striving for its own destruction at the hands of slaves (Bryusov); a harlot city dancing to the accompaniment of a devilish pianist that deprives citizens of will and individuality (Gatuev).
\end{abstract}

\section{Введение}

В литературе рубежа XIX-XX вв. городская тематика обрела новое звучание, соединив в себе противоречивые тенденции времени: развитие технологий, промышленности, экономики, философской мысли и одновременно расцвет декаданса в искусстве, одиночество и потерянность личности на фоне всеобщего движения вперед. Поэзия урбанизма, пользуясь мифологемами, архетипическими кодами, создавала эпическую картину существования мегаполисов, где смешивались традиции прошлого в суетливых буднях настоящего, с трагическим видением грядущих эсхатологических событий приближающегося XX века.

Актуальность данного исследования строится на необходимости выявления путей трансформации мифологических элементов в образной структуре урбанистической поэзии европейской, русской, осетинской литературы рубежа XIX-XX вв., что позволяет, в свою очередь, глубже понять тенденции развития «городского текста» XXI века. Задачи ставятся следующие:

1) проанализировать стихотворения со скрытыми в них мифологическими кодами, зашифрованными в поэтических образах и тропах;

2) определить роль анимизма в воссоздании лика современного города в литературе символизма.

Для решения поставленных задач использовались методы исследования: сравнительно-исторический, сравнительно-типологический, культурно-мифологический, метод целостного анализа художественных произведений. Теоретической базой явились труды отечественных ученых-филологов, литературоведов, философов, посвященные изучению теории мифа как такового и контексте городской культуры: А. Ф. Лосева [13],

Научная статья (original research article) । https://doi.org/10.30853/phil210336

(๔ 2021 Авторы. ООО Издательство «Грамота» (๔ 2021 The Authors. GRAMOTA Publishers). Открытый доступ предоставляется на условиях лицензии СС ВY 4.0 (open access article under the CС BY 4.0 license): https://creativecommons.org/licenses/by/4.0/ 
М. Ю. Лотмана [14], 3. Г. Минц [15], Р. Барта [3]; работы Л. А. Колобаевой [11], Л. Г. Андреева [1], В. Я. Брюсова [6] по эстетики зарубежного и русского символизма; материалы по истории осетинской литературы рубежа ХІХ-ХХ вв. (И. С. Хугаев [17]).

Практическая значимость результатов исследования заключается в возможности использования их в преподавании курсов по истории осетинской литературы на филологических факультетах PCO-А.

По словам видного ученого-филолога 3. Г. Минц, «всякое произведение искусства - миф» [15, с. 83], что говорит об исконной связи мифологии и литературы, прослеживающейся на всем протяжении развития последней. В творчестве любого поэта и писателя можно найти знаки, в которых мифологическое сознание проявляется на уровне генерации собственных авторских метафор, поскольку, по мнению русского философа и деятеля культуры А. Ф. Лосева, миф - «необходимая категория сознания и бытия вообще» [13, с. 95], а любой творческий процесс основывается, в свою очередь, на воображении, чьи «возможности... беспредельны» [4, с. 683]. Произведения художественной литературы создают, с одной стороны, мир уникальный, с другой - универсальный, поскольку обращаются к мифологической символике, которая заключает в себе «функцию “языка", “шифра-кода”, проясняющего тайный смысл происходящего» [15, с. 93]. Продолжая мысль о многофункциональности мифа как такового, французский философ, литературовед, теоретик постструктурализма Ролан Барт утверждает, что «мифом может быть всё» [3, с. 265].

В литературе рубежа XIX-XX веков в период поиска новых форм выразительности и обновления поэтического языка зарождается такая форма мышления, как неомифологизм, - обновленный вид контакта мифа и художественного творчества, где первый становится необходимым связующим звеном, «“ключом”, “шифром” для разгадки глубинной сущности происходящего в истории, современности и искусстве» [15, c. 83].

Символизм как первое течение модернизма, соединив в себе основные тенденции эпохи, регулярно обращается к поэтике мифа. Трансформация мифологических кодов прослеживается в урбанистической лирике поэтов-символистов Э. Верхарна (1855-1916), В. Я. Брюсова (1873-1924) и у осетинского писателя, публициста Д. А. Гатуева (1892-1938). Предметом анализа станут три стихотворения: «Город» Э. Верхарна из сборника «Поля в бреду» (1893) в переводе Г. Шенгели; «Городу» (1907) В. Брюсова и «Столица» (1914) Д. Гатуева.

\section{Образ города в творчестве Эмиля Верхарна}

Эмиля Верхарна заслуженно считают родоначальником «городского текста» рубежа XIX-XX веков. Бельгийский классик создает образ мощного, многоликого промышленного гиганта, который, разрастаясь грандиозными темпами, аналогично богам древности лишен четких градаций добро/зло, милосердие/жестокость, он есть данность, неизбежность, средоточие людских стремлений и чаяний. Верхарн поймал нерв современности, смог отразить актуальные процессы действительности через связь времен, его поэзия «похожа на могучий поток, который стремится охватить все, вовлечь в свое течение само существование человека и общества» [1, с. 14].

В стихотворении «Город» Верхарн воспевает могучее мифическое существо - город-спрут. Эта метафора рефреном проходит от начала и до конца текста, становясь главным смысловым центром:

«То - город-спрут

Лег

У дорог лавиной над равниной» [7, с. 105].

«То - город-спрут,

Горящий осьминог,

Костехранилище, скелет, великий остов» [Там же, с. 108].

Щупальца урбанического осьминога охватывают всё на своем пути, оплетают людей паутиной улиц и домов. Автор использует средства художественной выразительности анимистического характера для репрезентации города как живого организма:

«Там крылья крыш над чернотою ниш

Застылый свой полет в свинцовый свод несут» [Там же, с. 105].

«Все крыши, своды, все дворцы, все рынки,

Лицом к лицу, как бы на поединке.

Кругом - движенье кебов, стук колес,

Бег поездов, полет усилий...

Путей железных осеняя мили.

И рельсы тонкие змеятся под землей» [Там же, с. 106].

Верхарн воссоздает город как некую мифологическую среду и наделяет ее антропоморфными чертами, чтобы показать тождественность процессов существования одушевленных объектов и неодушевленных в пределах одного пространства.

В истории культуры символика города занимает особое место как универсальная картина постижения мира и отражение истории человечества. Это вертикаль, идущая вверх из глубин веков, как шпили церквей, соборов. Зачастую город, «как посредник между землей и небом» [14, с. 209], строился на горе, которая «выполняет ту же функцию, как мировое древо, связывающее небо, землю и подземный мир, и как лестница, 
по которой души восходят на небо» [9]. Тем самым мифологические традиции проявляются в архитектурном решении городов, в их нацеленности на будущее, в некой бесконечной надежде подняться по ступеням к Богу.

Образ символической лестницы встречается и в стихотворении Верхарна, он открывает его:

«Из глубины туманов

Нагроможденьем этажей,

Сплетеньем лестниц, бегом ступеней,

Несущихся все выше, все быстрей, -

Он возникает, как виденье, в небо прянув» [7, с. 105].

Согласно Библии, Иаков видел сон: «...вот, лестница стоит на земле, а верх ее касается неба; и вот, Ангелы Божии восходят и нисходят по ней» (Быт. 28:12), что трактуется как божественное откровение о пришествии Христа. Лестница репрезентирует связь земного и божественного, воплощает стремление к очищению и спасению; однако в тексте Верхарна она трансформируется в строение, не предназначенное для передвижения ангелов из-за хаотичного нагромождения и сплетенья ступеней, она словно фантом в тумане, где от сакрального компонента остается одно лишь направление ввысь. Лестница Иакова - элемент христианской мифологии - в урбанистической поэзии Верхарна приобретает дополнительную коннотацию, поскольку город «сам производит символы и смыслы» [12, с. 33], основываясь на уже существующих.

Стремясь к небесам, мегаполис Верхарна тем не менее грязнет в грехах, страданиях и смерти:

«И толпы, меж домами сжаты, -

В руках безумие, и ненависть в шагах,

И жар горячечный в глазах, -

Вонзают зубы в мчащееся время.

$<\ldots>$

Бескровный голод и разврат

Совокупляются в своих берлогах сорных,

И муки плоти черный танец мчат,

Смертельный танец, в переулках черных» [7, с. 106-107].

Бельгийский поэт, как Микеланджело рубежа веков, в живописных строках воплощает картину души города, где люди, улицы, дома, конторы, бары сливаются в некий болезненный пульсирующий клубок. Для символистов, как правило, город олицетворяет «современную цивилизацию с ее социальными контрастами, тотальной несвободой и моральными пороками» [18], так и у Верхарна он переполнен низменными страстями:

«И похоть в громе уличном растет,

И делается ярость ураганом,

И в давке дикой мчит людей вперед

Стремленье к наслажденьям пьяным

Из золота и фосфора» [7, с. 107].

Цвет и свет мегаполиса у Верхарна - это золото и фосфор, то есть богатство и блеск - цель развития человеческого общества. По мнению автора, погоня за успехом и достатком достигла апогея, обесцениваясь в стремительном хаосе существования.

Религиозная мифология используется в тексте для создания обреченного города, грешного, что отсылает к Каину, его первому основателю: «И построил он город; и назвал город по имени сына своего» (Быт. 4:17), и далее к Вавилонской башне: «И сказали они: построим себе город и башню, высотою до небес, и сделаем себе имя, прежде нежели рассеемся по лицу всей земли» (Быт. 11:4). В жажде возвыситься до уровня Господа человечество потерпело крах, став разобщенным сообществом, говорящим на множестве языков вместо единого и общепонятного. Можно утверждать, что из библейского прошлого берет начало тип горожанина одинокого, потерянного в каменных джунглях улиц и авеню. Мифологическими прототипами современного мегаполиса выступают также библейские распутные Содом и Гоморра, наполненные злостью и грехами, за что «пролил Господь на Содом и Гоморру дождем серу и огонь от Господа с неба, и ниспроверг города сии, и всю окрестность сию, и всех жителей городов сих» (Быт. 19:24-25). Грядущие разрушения предвидел и Верхарн, чья поэзия - отражение отблеска катастроф, войн и революций будущего ХХ века.

Город Верхарна, будучи средоточием страстей и людских страданий, тем не менее не лишается надежды, стихотворение открывается образом лестницы, направленной ввысь, этим же стремлением оно и завершается:

«То город над равниною встает

Как черное надежд огромных пламя.

Возносит он желанья, жизнь и свет.

Его свечения в ночное небо всходят,

Кустами золота горячий газ воздет,

И рельсы тонкие уводят

Глаза к обманчивой мечте» [Там же, с. 108]. 
К небесам поднимаются чаяния неонового гиганта как новой формы бытия в извечной погоне за счастьем и искуплением. В этом порыве есть гротескная двойственность: звезды - источник истинного света, а земля - иллюзий.

Город-спрут Верхарна - метафора, включающая в себя как визуальные элементы: дороги, улицы, железнодорожные рельсы-щупальца, - так и коннотацию мифологическую, где осьминог «соотносится с паутиной и спиралью, является символом как мистического Центра, так и разворачивающегося творения» [10, с. 372]. Мегаполис бельгийского классика является основой современности, он - огромный футуристический организм, находящийся в постоянном развитии и движении.

\section{Репрезентация «городского текста» в поэзии В. Я. Брюсова}

В русской поэзии символизма урбанистическая тематика ярче всего представлена в творчестве В. Я. Брюсова, где также присутствуют новые интерпретации известных мифологем.

В стихотворении «Городу», жанр которого сам автор определил как дифирамб, Валерий Яковлевич сравнивает город с драконом - древнейшей символической фигурой, которая встречается в большинстве культур мира - от примитивных до классических; это собирательный тип врага, дьявол, победа над которым означает свержение мирового и космического зла (библейские сюжеты о святом Георгии, святом Архангеле Михаиле).

У Брюсова дракон воплощает собой современный мегаполис, он - хтоническое чудище, «появляется восседающим на троне подобно божествам» [Там же, с. 183] охраняющим сокровища:

«Драконом, хищным и бескрылым,

Засев - ты стережешь года,

А по твоим железным жилам

Струится газ, бежит вода.

$<\ldots>$

Ты, хитроумный, ты, упрямый,

Дворцы из золота воздвиг» [5, с. 514].

Архаический образ у В. Я. Брюсова трансформируется в собирательный конструкт, средоточие исторической памяти человечества в механизированном, электрическом гиганте, который хранит прошлое, генерирует настоящее и предвосхищает будущее; как справедливо отмечает доктор филологических наук, профессор Л. А. Колобаева, «миф в поэзии Брюсова - чаще всего мост времени» [11, с. 144]. Дракон в тексте предстает бескрылым, он принадлежит только земле и является источником главных пороков человечества, которые становятся именами собственными, это краеугольные камни существования города (Злоба, Нищета, Безумье, Гордость, Нужда, Разврат):

«Твоя безмерная утроба

Веков добычей не сыта, -

В ней неумолчно ропщет Злоба,

В ней грозно стонет Нищета.

$<\ldots>$

И шлешь вождей на митинг черный:

Безумье, Гордость и Нужду!

$<\ldots>$

И в ночь, когда в хрустальных залах

Хохочет огненный Разврат» [5, с. 514-515].

Вскрывая проблемы мегаполиса, автор при этом восхищается его силой и мощью:

«Царя властительно над долом,

Огни вонзая в небосклон,

Ты труб фабричных частоколом

Неумолимо окружен.

Стальной, кирпичный и стеклянный,

Сетями проволок обвит,

Ты - чарователь неустанный,

Ты - не слабеющий магнит» [Там же, с. 514].

По аналогии с Верхарном, для Брюсова важна притягательная сила города, где также присутствуют библейские аллюзии (Вавилонская башня, лестница Иакова).

В мегаполисе Валерия Яковлевича сконцентрированы все радости и горести человеческой жизни, а акцент ставится на негативной составляющей: страдания, нужда, голод и грех; это город Каина. Подобная отрицательная коннотация отличает видение символистов в целом, где «урбанистический топос... становится пространственной моделью “града обреченного”, в котором превалирует архетипический сюжет грядущего 
апокалипсического разрушения» [18]. Поэзия Брюсова также отличается чертой эсхатологического предвидения. В стихотворении «Городу» автор указывает на его печальную участь как организма порочного, который, задыхаясь злобой, карает сам себя:

«Ты гнешь рабов угрюмых спины,

Чтоб, исступленны и легки,

Ротационные машины

Ковали острые клинки.

Коварный змей с волшебным взглядом!

В порыве ярости слепой,

Ты нож, с своим смертельным ядом,

Сам подымаешь над собой» $[5$, с. 515$]$.

Жители готовятся к бунту и в недрах механического города-тирана печатают листовки - «острые клинки» информационной войны, вынашивают силу, которая разогнет их спины в огне апокалипсиса-революции 1917 года. Сила лирики рубежа XIX-XX вв. - в способности предчувствовать будущее, поскольку только поэты, по словам Брюсова, обладают «сверхчувственной интуицией» и дают «иные постижения мировых явлений, глубже проникающие за их внешнюю кору, в их сердцевину» [6, с. 92]. В анализируемом тексте Брюсова отражается мощь города-дракона, неумолимым темпом стремящегося к собственной гибели. Тем самым урбанический топос В. Я. Брюсова - это средоточие конкретики современности на мифологической основе, где реализуется авторская модель мира, в котором все элементы «обретают обобщенно-символический, провиденциальноэсхатологический характер» [2, с. 23].

\section{Городская символика в осетинской лирике рубежа XIX-XX вв. (Д. А. Гатуев)}

Осетинский писатель, поэт, публицист и общественный деятель Дзахо (Константин) Алексеевич Гатуев соединил в своей литературной деятельности традиции реализма и модернизма (в частности, символизма). С 1912 года, как отмечает исследователь творчества писателя И. С. Хугаев, поступив «на историко-филологический факультет Московского университета, Дзахо Гатуев испытывал сильное влияние современной русской литературы и, в частности, модернистских течений» $[17$, с. 5]. Символизм ярко проявился во многих культурах Европы, России, и не случайно его воздействие и на литературу Северного Кавказа начала XX века, поскольку, по словам 3. Г. Минц, «полисемантичность символистского текста обнажается в его внутренней структуре как осознанная поликультурность» [15, с. 94].

Урбанистическая тема нашла отражение в стихотворении Д. Гатуева «Столица», где автор обращается к мифологии современного города, к древнейшему воплощению зла - чёрту:

«Сидит на ржавой крыше чёрт.

Плюгавый, серокожий,

Он за аккордом бьет аккорд,

Смеясь и строя рожи.

Над ним звонят колокола

Восторг святых прелюдий.

Под ним с угла и до угла

Бредут уныло люди» [8, с. 15-16].

Чёрт, как и дракон у Брюсова, - это архетипичный образ, в славянской мифологии это дух, сформировавшийся под воздействием христианских представлений о дьяволе, антропоморфное рогатое существо с копытами и хвостом, покрытое шерстью. Характер многоплановый, яркий, подвижный, многоликий, «лукавый, враг, шут, окаяшка, черный, немытик» [16, с. 625]. Он вездесущий, всегда готов сбить людей с пути истинного, совратить, заморочить, подтолкнуть к преступлению, его главная цель - завладеть душой человека.

Перечисленные выше качества привлекли осетинского поэта в фантастическом персонаже, поскольку для Гатуева именно чёрт - истинный городской властелин, дьявольский манипулятор. Прыгая с крыши на крышу, смеясь над людьми, он бьет аккорды, где струны гитары - это нити кукловода, ведущие к каждому жителю столицы:

«Бредут, шагают мерно, в такт

Мотиву злому черта,

И ложь их блещет, как смарагд

На пальце девы мертвой.

От душ их кто-то протянул

К гитаре чёрта струны» [8, с. 16].

Движутся анемичные толпы, околдованные зловещим духом, при этом загадка в том, что не чёрт поймал их в сети дьявольских звуков, не он наслал морок и безволие - «кто-то» протянул нити к их душам. Возможно, уже сам факт рождения и жизни в больших городах лишает человека индивидуальности и превращает его 
в марионетку, вливая в общий поток аморфных существ, связанных одной цепью порока и обмана. Столица осетинского поэта лишена географического обозначения, это не конкретное место, а образ собирательный, лицо любого современного города. В тексте Гатуев использует и цветовую символику: смарагд (изумруд) воплощает ложные ценности и смерть чистых помыслов, что неслучайно, так как зеленый цвет изначально двоякий, он продукт смешения желтого (воплощение предательства и болезней) с голубым (божественное откровение, бессмертие, благодать). Зеленые одеяния у Девы Марии, но также это и окрас глаз, кожи Змеяискусителя, цвет города-дракона Брюсова.

Заканчивается стихотворение Гатуева богатыми визуальными и музыкальными образами:

«И чёрт прядет, смеясь, узор

К мелодии столицы,

Как расстаравшийся тапер

Для пьяных pas блудницы» [Там же].

Портрет города сплетается из узоров и звуков не только гитарных струн и душ людей, но и из гипнотических фортепианных мелодий чёрта, под которые танцует пьяная блудница. Этот образ взят из Откровения Иоанна Богослова: «...подойди, я покажу тебе суд над великою блудницею, сидящею на водах многих; с нею блудодействовали цари земные, и вином ее блудодеяния упивались живущие на земле» (Откр. 17:1). Создавая универсальный лик современного мегаполиса, автор наделяет его чертами зла мифологического: чёрт, питающийся человеческими грехами, блудница, опаивающая вином порока людей. Город движется под дьявольские звуки, толпы безвольно бредут вперед, столица блещет изумрудами лжи и обмана, совращая девунадежду, которая умирает и возрождается в пьяной распутнице.

\section{Заключение}

В итоге исследования приходим к следующим выводам.

Мифология современного города в поэзии рубежа веков создается с помощью антропоморфных и анимистических образов: у Верхарна - город-спрут, у Брюсова - дракон, у Гатуева - чёрт. Тем самым авторы репрезентируют мегаполис как живое существо с улицами-щупальцами осьминога (Верхарн), с трубами-венами, по которым бежит кровь города - газ и электричество (Брюсов), с множеством личин - от черта-кукловода до танцующей блудницы (Гатуев).

Мифологемы, которые встречаются в текстах, в основном библейские: лестница Иакова, Содом и Гоморра, Вавилонская башня, Вавилонская блудница, город Каина. Поэты актуализируют извечные образы, обогащают их новым значением: лестницы-города стремятся в небеса, но в хаотичном нагромождении теряют не только свою божественную цель, но и сам вектор движения ввысь по прямой (Верхарн); похоть, нищета, моральные пороки, процветающие в современных Содоме и Гоморре, неизбежно ведут к гибели, к эсхатологическому огню грядущих революций и социальных преобразований (Брюсов); Вавилонская блудница как обратная сторона Пресвятой Девы в мегаполисе, лишающем индивидуальности и свободы воли, где каждый житель обречен на гибель и деградацию (Гатуев).

Таким образом, город в поэзии Верхарна, Брюсова, Гатуева создается объемным, динамичным, авторы используют как религиозные аллюзии, так и цветовую и музыкальную составляющие, обогащая поэтику произведений, углубляя авторскую картину миромоделирования. Индивидуальный портрет города в поэзии символизма вплетается в универсальный, это новый макрокосм, живой организм, который через анимистические образы, базируясь на мифологической основе, питаясь культурой прошлого, отчаянно устремлен в черную пропасть будущего, в эпоху свершений, достижений и катастроф XX века.

В ходе проделанной работы открывается перспектива для дальнейшего исследования урбанистической поэзии в европейской, русской и осетинской литературе второй половины XX века.

\section{Источники | References}

1. Андреев Л. О двух знаменитых бельгийцах // Верхарн Э. Стихотворения; Зори: драма. Метерлинк М. Пьесы. М.: Худож. лит., 1972. С. 5-28.

2. Бараханова И. В., Игонина С. В., Павлова Т. Л. «Городской текст» в творчестве Валерия Брюсова // Казанская наука. 2019. № 12. С. 21-23.

3. Барт Р. Мифологии / пер. с фр. С. Зенкина. М.: Академический Проект, 2008. 351 с.

4. Бодлер Ш. Статьи об искусстве. Салон 1859 года. Божественный дар / пер. с фр. Н. Столяровой, Л. Липман // Бодлер Ш. Цветы зла. Обломки. Парижский сплин. Искусственный рай. Эссе, дневники. Статьи об искусстве. М.: РИПОЛ классик, 1997. С. 669-749.

5. Брюсов В. Я. Городу // Брюсов В. Я. Собрание сочинений: в 7-ми т. / под общ. ред. П. Г. Антокольского и др. М.: Худож. лит., 1973. Т. 1. Стихотворения. Поэмы. 1892-1909. С. 514-515.

6. Брюсов В. Я. Ключи тайн // Брюсов В. Я. Собрание сочинений: в 7-ми т. / под общ. ред. П. Г. Антокольского и др. М.: Худож. лит., 1975. Т. 6. Статьи и рецензии 1893-1924. Из книги «Далекие и близкие». С. 78-93.

7. Верхарн Э. Избранное. М.: Гос. изд-во худож. лит., 1955. 552 с. 
8. Гатуев К. А. Стакан шейха. Орджоникидзе: Ир, 1981. 438 с.

9. Гурин С. П. Образ города в культуре: метафизические и мистические аспекты [Электронный ресурс]. URL: http://www.comk.ru/HTML/gurin_doc.htm (дата обращения: 31.03.2021).

10. Керлот Х. Э. Словарь символов / пер. с исп. Н. А. Богун, Ю. А. Данько и др. M.: REFL-book, 1994. 608 c.

11. Колобаева Л. А. Русский символизм. М.: Изд-во Моск. ун-та, 2017. 352 с.

12. Кузнецова А. В., Петрулевич И. А. Миф и мифологема города в тексте культуры: социологический и лингвокогнитивный аспекты // Известия высших учебных заведений. Северо-Кавказский регион. Общественные науки. 2015. № 4 (188). С. 32-36.

13. Лосев А. Ф. Диалектика мифа. М.: Мысль, 2001. 558 с.

14. Лотман Ю. М. Символика Петербурга и проблема семиотики города // Лотман Ю. М. История и типология русской культуры. СПб.: Искусство - СПб, 2002. С. 209-220.

15. Минц 3. Г. О некоторых «неомифологических» текстах в творчестве русских символистов // Творчество А. А. Блока и русская культура ХХ века. Блоковский сборник III. Тарту: ТГУ, 1979. С. 76-120.

16. Мифы народов мира: энциклопедия: в 2-х т. / гл. ред. С. А. Токарев. Изд-е 2-е. М.: Советская энциклопедия, 1988. Т. 2. К (Корибанты) - Я. 671 с.

17. Хугаев И. С. Дальше на Восток: к вопросам поэтики Дзахо Гатуева // Вестник Владикавказского научного центра. 2018. № 4 (18). С. 4-8.

18. Шмидт Н. В. Введение диссертации (часть автореферата) [Электронный ресурс] // Шмидт Н. В. «Городской текст» в поэзии русского модернизма: автореф. дисс. ... к. филол. н. URL: https://www.dissercat.com/content/ gorodskoi-tekst-v-poezii-russkogo-modernizma (дата обращения: 31.03.2021).

\section{Информация об авторах | Author information}

RU Хетагурова Дзерасса Казбековна ${ }^{1}$, к. филол. н.

${ }^{1}$ Владикавказский научный центр Российской академии наук

EN Khetagurova Dzerassa Kazbekovna ${ }^{1}, \mathrm{PhD}$

${ }^{1}$ Vladikavkaz Scientific Center of the Russian Academy of Sciences

${ }^{1}$ dze-khe@yandex.ru

\section{Информация о статье | About this article}

Дата поступления рукописи (received): 15.06.2021; опубликовано (published): 30.07.2021.

Ключевые слова (keywords): городская поэзия; мифология; Э. Верхарн; В. Я. Брюсов; Д. А. Гатуев; urban poetry; mythology; É. Verhaeren; V. Ya. Bryusov; D. A. Gatuev. 